\title{
Pengaruh Perceived Burdensomeness, Thwarted Belongingness, dan Religiusitas Terhadap Ideasi Bunuh Diri pada Lansia
}

\author{
Desy Ramadhani Harahap, IImi Amalia \\ Fakultas Psikologi UIN Syarif Hidayatullah Jakarta \\ Corresponding E-mail: desyrharahap@gmail.com
}

\begin{abstract}
Suicidal ideation in elderly is rarely a society's concern even though elderly is the age group most vulnerable to suicide. This study was conducted to prove the effect of perceived burdensomeness, thwarted belongingness, religiosity, and demographic factors (gender and education level) on suicidal ideation in the elderly. The subjects of this study were 230 respondents aged 60 years and over who were obtained using accidental nonprobability sampling techniques. The measuring instrument used were the adaptation and modification of the Geriatric Suicide Ideation Scale, the Interpersonal Needs Questionnaire, and the Centrality of Religiosity Scale. The validity test of the instrument was carried out using Confirmatory Factor Analysis (CFA), while the hypothesis testing was carried out using multiple regression analysis. The results showed that there was a significant effect of perceived burdensomeness and the ideological dimensions of religiosity. The results of this study are expected to be an input for readers to pay more attention to the perceived burdensomeness and ideology of religiosity in the elderly as factors that can influence suicidal ideation. Subsequent researchers can also develop this research by adding other independent variables to be analyzed, such as health conditions and living arrangements.
\end{abstract}

Keywords: Elderly; Perceived burdensomeness; Religiosity; Suicidal ideation; Thwarted belongingness

\begin{abstract}
Abstrak
Ideasi bunuh diri pada lansia jarang diperhatikan oleh masyarakat meski pada kenyataannya lansia adalah kelompok umur yang paling rentan dengan aksi bunuh diri. Penelitian ini dilakukan untuk membuktikan pengaruh perceived burdensomeness, thwarted belongingness, religiusitas, serta faktor demografi (jenis kelamin dan tingkat pendidikan) terhadap ideasi bunuh diri pada lansia. Subjek dari penelitian ini adalah 230 responden berusia 60 tahun keatas yang diperoleh menggunakan teknik accidental non-probability sampling. Alat ukur yang digunakan adalah adaptasi serta modifikasi dari Geriatric Suicide Ideation Scale, Interpersonal Needs Questionnaire, serta Centrality of Religiosity Scale. Uji validitas instrumen dilakukan dengan menggunakan Confirmatory Factor Analysis (CFA), sedangkan uji hipotesis dilakukan dengan analisis regresi berganda. Hasil penelitian menunjukkan adanya pengaruh yang signifikan dari perceived burdensomeness dan dimensi ideologi dari religiusitas. Hasil penelitian ini diharapkan dapat menjadi masukan bagi pembaca untuk lebih memperhatikan perceived burdensomeness dan ideologi religiusitas pada lansia sebagai faktorfaktor yang dapat mempengaruhi ideasi bunuh diri. Peneliti berikutnya juga dapat mengembangkan penelitian ini dengan menambah variabel independen lainnya untuk dianalisis seperti kondisi kesehatan serta living arrangement.
\end{abstract}

Kata kunci: Ideasi bunuh diri; Lansia; Perceived burdensomeness; Religiusitas; Thwarted belongingness, 


\section{Pendahuluan}

Dalam beberapa tahun terakhir, bunuh diri menjadi fenomena yang sering muncul dalam pemberitaan media. Menurut World Health Organization (2016a) hampir 800.000 orang meninggal karena bunuh diri setiap tahunnya, yang bisa dikatakan satu orang tiap 40 detik. Bunuh diri tidak mengenal usia. Baik remaja, dewasa, lansia, bahkan anak-anak tidak terlepas dari kasus bunuh diri (WHO 2016b). Spesifiknya, berdasarkan statistik dari WHO (2016b) kelompok usia yang paling banyak melakukan bunuh diri hampir di seluruh dunia adalah lansia, terutama lansia akhir yang berumur 80 tahun ke atas. Institute for Health Metrics and Evaluation (IHME) dalam ourworldindata.org melaporkan bahwa bunuh diri tertinggi di Indonesia terjadi pada penduduk berusia 70 tahun ke atas (Jayani, 2019). Pelaku bunuh diri lansia di Indonesia sendiri kebanyakan memilih gantung diri sebagai cara mengakhiri nyawa. Lansia Indonesia juga diduga melakukan aksi bunuh diri dikarenakan kesepian, depresi, serta penyakit yang berkelanjutan (Khalik, 2020; Pangaribowo, 2019; Pertana, 2019).

Sayangnya jika dibandingkan dengan fakta-fakta tersebut, fenomena bunuh diri pada lansia kurang diulas oleh media. Alasannya dikarenakan kurangnya dampak bunuh diri oleh lanjut usia pada masyarakat dibandingkan populasi yang lebih muda. Ini mungkin disebabkan oleh dampak ekonomi bunuh diri lansia yang lebih rendah pada masyarakat, karena sebagian besar lansia tidak termasuk angkatan kerja, dan sisa umur yang tersisa memang tidak begitu banyak lagi (Dombrovski dkk, 2005 dalam Crestani, Masotti, Corradi, Schirripa, \& Cecchi, 2019). Padahal, lansia tetap berkontribusi terhadap masyarakat. Lansia masih mengonsumsi barang dan jasa, masih pula membayar pajak. Lansia juga mampu membantu mengasuh cucu dan mengerjakan pekerjaan rumah. Dengan bantuannya, anggota keluarga lain dapat melakukan kegiatan lainnya seperti bekerja dan mengenyam pendidikan. Oleh sebab itu, lansia secara tidak langsung juga berkontribusi terhadap ekonomi negara (Menec, 2012). Selain itu, dikarenakan peningkatan populasi lansia yang dikaitkan dengan peningkatan angka harapan hidup, bunuh diri akan menjadi masalah yang lebih serius di kemudian hari (Jung, Roh, Moon, \& Kim, 2017).

Dalam pengerucutan tema penelitian, peneliti mengacu pada David Klonsky \& May (2015) yang melakukan pengembangan sebuah kerangka teori bunuh diri baru yang disebut The Three-Step Theory: "Ideation-to-Action". Kerangka ini memiliki arti bahwa perilaku bunuh diri selalu diawali dengan ideasi bunuh diri. Berdasarkan teori ini peneliti kemudian mencoba mengidentifikasi perilaku bunuh diri dengan ideasi 4 bunuh diri. Ideasi bunuh diri di sini digambarkan dengan pemikiran tentang kematian dan keinginan mati yang relatif ringan hingga pikiran serius tentang rencana dan cara bunuh diri (Reynolds, 1991).

Ideasi bunuh diri mengacu pada pikiran melakukan perilaku yang dimaksudkan untuk mengakhiri hidup diri sendiri (Nock et al., 2008). Ideator bunuh diri adalah individu yang saat ini memiliki rencana dan keinginan untuk bunuh diri tetapi belum pernah melakukan upaya bunuh diri secara terbuka. Ide bunuh diri secara logis mendahului upaya bunuh diri atau perilaku bunuh diri (Beck \& Kovacs, 1979). Joiner (2005) dalam bukunya Why People Die by Suicide menyebutkan bahwa faktor utama yang menimbulkan gagasan bunuh diri pada individu adalah kombinasi antara perceived burdensomeness yang tinggi serta thwarted belongingness. Teori ini disebut Interpersonal Theory of Suicide.

Perceived burdensomeness memiliki definisi perasaan menjadi beban lingkungan. Konstruk ini dianggap paling mungkin terjadi pada lansia yang sedang mengalami masa transisi pensiun. Lansia merasa tertekan ketika mereka mulai membutuhkan lebih banyak perawatan dari anggota keluarga atau jaringan pertemanan mereka, sehingga lansia mungkin menganggap diri mereka beban dan ideasi bunuh diri mulai muncul (Cukrowicz, Cheavens, Orden, Ragain, \& Cook, 2011). Perceived burdensomeness juga berkaitan erat dengan kondisi kesehatan. Melihat kondisi lansia di Indonesia yang sebesar $26.20 \%$ menderita penyakit serta 51.8\% mengalami keluhan kesehatan (Maylasari et al., 2019), perceived burdensomeness dapat disimpulkan rentan dialami lansia Indonesia. Kanzler, Bryan, Mcgeary, \& Morrow (2012) pada penelitiannya menemukan adanya pengaruh signifikan antara 
perceived burdensomeness dan ideasi bunuh diri pada lansia, sedangkan penelitian dari Campos, Santos, Piteira, Abreu, \& Tavares (2018) sebaliknya, tidak menemukan adanya korelasi yang signifikan antara dua variabel tersebut. Konstruk berikutnya dari teori interpersonal, yaitu thwarted belongingness, yang dideskripsikan sebagai perasaan terasingkan dari lingkungan sosial. Penelitian dari McLaren, Gomez, Gill, \& Chesler (2015) menyimpulkan bahwa thwarted belongingness memediasi ideasi bunuh diri pada kelompok dewasa akhir dengan status pernikahan. Campos, Santos, Piteira, Abreu, \& Tavares (2018) juga mengatakan thwarted belongingness secara statistik memprediksi ideasi bunuh diri pada penelitiannya terhadap pasien lansia dengan riwayat penyakit medis akut. Menurut opini penulis sendiri, mudah bagi lansia merasa asing ketika ia tinggal bersama keluarga dan anak-anaknya di mana ia menjadi minoritas, sehingga memungkinkan terjadinya diskrepansi pola pikir antar generasi. Alasan ini kemudian dapat memicu pikiran-pikiran bunuh diri pada lansia. Sehubungan dengan itu, dihipotesiskan bahwa perceived burdensomeness dan thwarted belongingness mempengaruhi ideasi bunuh diri pada lansia.

Ideasi bunuh diri pada lansia juga dapat dipengaruhi oleh religiusitas. Menurut Huber \& Huber (2012), definisi religiusitas adalah intensitas, makna, kepentingan, serta sentralitas agama dalam individu. Satrianegara (2014) yang mengartikan religiusitas sebagai kepatuhan pada agama menyebutkan bahwa religiusitas dalam Islam seperti melaksanakan salat, puasa dan sebagainya. Penelitian dari Jung, Roh, Moon, \& Kim (2017) menemukan bahwa religiusitas 1180 lansia Korea yang beragama Kristen dan Buddha berkorelasi secara negatif dengan ideasi bunuh diri. Dalam Islam, Hal ini mungkin disebabkan karena pemahaman kolektif dari kitab suci Al-Qur'an yang menekankan kesucian hidup dan larangan membunuh. Selain itu, kumpulan hadis-hadis Nabi secara eksplisit dan tegas tidak hanya mengharamkan bunuh diri tetapi juga mengutuk pelakunya. Tradisi Nabi tidak hanya melarang bunuh diri tetapi juga secara eksplisit mencegah keinginan untuk mati (Shah \& Chandia, 2010). Penulis juga berasumsi dimensi ibadah dapat mengurangi tingkat ideasi bunuh diri seseorang dengan menjadikan ibadah sebagai salah satu mekanisme coping ketika menghadapi stress. Selain itu, alasan korelasi negatif ideasi bunuh diri dengan dimensi pengalaman religius diasumsikan dengan merasakan keberadaan sosok spiritual yang lebih tinggi dapat membuat individu merasa ada yang menemani serta menjaga bahkan di saat-saat sulit sehingga mereduksi keinginan untuk melakukan bunuh diri. Pada umumnya, seiring dengan meningkatnya usia, makin meningkat pula religiusitas seseorang. Persepsi ini dibuktikan oleh penelitian dari Bengtson, Silverstein, Putney, \& Harris (2015) yang menyatakan terdapat korelasi positif antara umur dengan intensitas dan kepercayaan agama. Kemudian muncul pertanyaan, apabila lansia memiliki religiusitas yang tinggi dan agama Islam melarang perilaku bunuh diri, mengapa lansia menduduki angka bunuh diri tertinggi di Indonesia? Apakah benar korelasi negatif antara religiusitas dan ideasi bunuh diri pada lansia indonesia? Karena pertanyaan-pertanyaan tersebutlah peneliti berusaha memprediksi pengaruh religiusitas terhadap ideasi bunuh diri pada lansia di Indonesia. Oleh karena itu, dihipotesiskan religiusitas mempengaruhi ideasi bunuh diri pada lansia.

Variabel lain yang dapat mempengaruhi bunuh diri pada lansia adalah demografi. Variabel ini disini terdiri dari jenis kelamin dan tingkat pendidikan. Terkait variabel jenis kelamin, terdapat beberapa perbedaan hasil temuan dimana Jang et al. (2014) menemukan lansia berjenis kelamin wanita lebih rentan terhadap ideasi bunuh diri, sedangkan Xu et al. (2016) menyebutkan tidak ada perbedaan signifikan antara lansia pria dan wanita dalam ideasi bunuh diri. Untuk tingkat pendidikan, Bickford, Morin, Nelson, \& Mackin (2019); Jang et al. (2014); Yu et al. (2019) menemukan adanya korelasi negatif antara tingkat pendidikan dengan ideasi bunuh diri. Namun hasil lain berkebalikan, semakin tinggi tingkat pendidikan lansia maka makin tinggi pula tingkat ideasi bunuh dirinya, sesuai dengan penelitian dari Ron (2008).

Keterbatasan akan penelitian serta ulasan mengenai ideasi bunuh diri pada lansia menunjukkan pentingnya tema ini untuk diteliti. Identiknya perceived burdensomeness dan thwarted belongingness terhadap kehidupan lansia serta ketidaksesuaian antara fakta dan teori dalam pengaruh religiusitas 
dan usia terhadap bunuh diri lansia menjadi alasan penulis memilih perceived burdensomeness, thwarted belongingness, serta religiusitas sebagai variabel untuk diteliti.

\section{Metode}

Total sampel dalam penelitian ini adalah 230 lansia berusia 60 tahun keatas dengan rata-rata usia 67,322 tahun $(\mathrm{SD}=6.62541$ ) yang mampu memahami kuesioner yang diberikan. Teknik pengambilan sampel yang digunakan adalah accidental non-probability sampling. Adapun pengambilan sampel dilakukan dengan menyebarkan kuesioner secara online menggunakan google form. Mengingat lansia rentan gagap serta lebih jarang menggunakan teknologi, peneliti dalam penyebaran kuesioner online lebih menargetkan orang-orang di sekitar lansia untuk membantu memberikan kuesioner ke lansia, dibandingkan memberikan kuesioner langsung ke lansia.

Tabel 1

Gambaran Demografi Subjek Penelitian

\begin{tabular}{lcc}
\hline Deskripsi & Jumlah (n) & Persentase (\%) \\
\hline Jenis Kelamin & 81 & \\
Pria & 149 & 35.2 \\
Wanita & & 64.8 \\
Pendidikan & 5 & \\
Tidak pernah sekolah & 3 & 2.2 \\
Tidak tamat SD & 56 & 1.3 \\
SD/sederajatnya & 26 & 24.3 \\
SMP/sederajatnya & 87 & 11.3 \\
SMA/sederajatnya & 53 & 37.8 \\
Perguruan Tinggi & & 23.0 \\
Status Situasi Hidup & 15 & \\
Sendiri & 32 & 6.5 \\
Hanya dengan pasangan & 97 & 14.0 \\
Dengan anak \& tanpa pasangan & 69 & 42.2 \\
Dengan pasangan \& anak & 3 & 30.0 \\
Dengan pasangan \& lainnya yang bukan anak & 14 & 1.3 \\
Lainnya (bukan anak \& pasangan) & & 6.1 \\
\hline Total Responden & & $\mathbf{2 3 0}$
\end{tabular}

Instrumen penelitian untuk mengukur ideasi bunuh diri merupakan adaptasi dari Heisel \& Flett (2006), yaitu Geriatric Suicide Ideation Scale atau GSIS. Alat ukur ini awalnya memiliki 31 item serta lima subskala yang mengukur ideasi bunuh diri, ideasi kematian, hilangnya nilai pribadi dan sosial dan makna kehidupan. Penulis memutuskan untuk hanya menggunakan subskala ideasi bunuh diri yang berisikan sepuluh item. Adapun contoh item GSIS adalah "Hidup ini sangat sulit dan saya ingin melarikan diri". Sementara instrumen untuk mengukur perceived burdensomeness dan thwarted belongingness adalah Interpersonal Needs Questionnaire atau INQ yang dirancang oleh Orden, Cukrowicz, Witte, \& Joiner (2012). Skala ini terdiri dari 15 item dengan enam item mengukur perceived burdensomeness dan sembilan item sisanya mengukur thwarted belongingness sesuai dengan Orden et al. (2012). Contoh item yang mengukur perceived burdensomeness adalah "Orangorang dalam hidup saya akan merasa lebih baik jika saya pergi". Terakhir, untuk mengukur religiusitas digunakan alat ukur dari Huber \& Huber (2012), yaitu Centrality of Religiosity Scale atau CRS yang terdiri dari 15 item dan 5 dimensi, mengikuti Huber \& Huber (2012), dengan contoh item "Saya selalu melaksanakan ibadah individual/ sendirian". Adaptasi alat ukur dilakukan dengan menerjemahkan serta menyesuaikan penggunaan bahasa tiap item agar lebih mudah dipahami oleh lanjut usia. 
Analisis yang digunakan pada uji validitas setiap alat ukur menggunakan Confirmatory Factor Analysis (CFA) untuk melihat model fit unidimensional dan item yang valid. Kemudian dalam menguji hipotesisi penelitian menggunakan analisis regresi berganda (multiple regression analysis) untuk melihat pengaruh variabel prediktor atau independent variable terhadap variabel kriteria atau dependent variable menggunakan estimasi true score.

\section{Hasil}

Tabel 2

Tabulasi Silang Ideasi Bunuh Diri dan Status Situasi Hidup

\begin{tabular}{|c|c|c|c|c|c|}
\hline & & & \multicolumn{2}{|c|}{ Bunuh diri } & \multirow[b]{2}{*}{ Total } \\
\hline & & & Rendah & Tinggi & \\
\hline \multirow[t]{24}{*}{ Living } & Sendiri & Count & 4 & 11 & 15 \\
\hline & & $\%$ within living & $26.7 \%$ & $73.3 \%$ & $100.0 \%$ \\
\hline & & $\%$ within bundir & $3.0 \%$ & $11.2 \%$ & $6.5 \%$ \\
\hline & & $\%$ of Total & $1.7 \%$ & $4.8 \%$ & $6.5 \%$ \\
\hline & Pasangan & Count & 19 & 13 & 32 \\
\hline & & $\%$ within living & $59.4 \%$ & $40.6 \%$ & $100.0 \%$ \\
\hline & & $\%$ within bundir & $14.4 \%$ & $13.3 \%$ & $13.9 \%$ \\
\hline & & $\%$ of Total & $8.3 \%$ & $5.7 \%$ & $13.9 \%$ \\
\hline & Anak & Count & 57 & 40 & 97 \\
\hline & & $\%$ within living & $58.8 \%$ & $41.2 \%$ & $100.0 \%$ \\
\hline & & $\%$ within bundir & $43.2 \%$ & $40.8 \%$ & $42.2 \%$ \\
\hline & & $\%$ of Total & $24.8 \%$ & $17.4 \%$ & $42.2 \%$ \\
\hline & Anak dan & Count & 41 & 28 & 69 \\
\hline & pasangan & $\%$ within living & $59.4 \%$ & $40.6 \%$ & $100.0 \%$ \\
\hline & & $\%$ within bundir & $31.1 \%$ & $28.6 \%$ & $30.0 \%$ \\
\hline & & $\%$ of Total & $17.8 \%$ & $12.2 \%$ & $30.0 \%$ \\
\hline & Pasangan dan & Count & 1 & 2 & 3 \\
\hline & lainnya & $\%$ within living & $33.3 \%$ & $66.7 \%$ & $100.0 \%$ \\
\hline & & $\%$ within bundir & $0.8 \%$ & $2.0 \%$ & $1.3 \%$ \\
\hline & & $\%$ of Total & $0.4 \%$ & $0.9 \%$ & $1.3 \%$ \\
\hline & Lainnya & Count & 10 & 4 & 14 \\
\hline & & $\%$ within living & $71.4 \%$ & $28.6 \%$ & $100.0 \%$ \\
\hline & & $\%$ within bundir & $7.6 \%$ & $4.1 \%$ & $6.1 \%$ \\
\hline & & $\%$ of Total & $4.3 \%$ & $1.7 \%$ & $6.1 \%$ \\
\hline \multirow[t]{4}{*}{ Total } & & Count & 132 & 98 & 230 \\
\hline & & $\%$ within living & $57.4 \%$ & $42.6 \%$ & $100.0 \%$ \\
\hline & & $\%$ within bundir & $100.0 \%$ & $100.0 \%$ & $100.0 \%$ \\
\hline & & $\%$ of Total & $57.4 \%$ & $42.6 \%$ & $100.0 \%$ \\
\hline
\end{tabular}

Analisis tabulasi silang dilakukan untuk menggambarkan keterkaitan antar variabel secara sederhana. Pada penelitian ini, tabulasi silang dilakukan antara ideasi bunuh diri dan status situasi hidup menggunakan data mentah. Berdasarkan data di atas, dapat dilihat bahwa mayoritas lansia yang tinggal sendirian atau bersama pasangan serta orang lain lebih rentan mengalami ideasi bunuh diri pada kategori tinggi. Sedangkan lansia yang tinggal hanya bersama pasangan, hanya dengan anak, 
bersama pasangan dan anak, serta tinggal dengan orang lain lebih cenderung mengalami ideasi bunuh diri pada kategori rendah.

\section{Tabel 3}

Hasil CFA

\begin{tabular}{|c|c|c|c|c|c|c|}
\hline & Instrumen & Dimensi & Chi square & $d f$ & P-value & RMSEA \\
\hline 1 & $\begin{array}{l}\text { Geriatric } \\
\text { Suicide } \\
\text { Ideation Scale }\end{array}$ & & 20.86 & 14 & 0.10536 & 0.046 \\
\hline \multirow[t]{2}{*}{2} & $\begin{array}{l}\text { Interpersonal } \\
\text { Needs } \\
\text { Questionnaire }\end{array}$ & Perceived Burdensomeness & 6.16 & 4 & 0.18769 & 0.049 \\
\hline & & Thwarted Belongingness & 8.35 & 6 & 0.21379 & 0.041 \\
\hline \multirow[t]{4}{*}{3} & $\begin{array}{l}\text { Centrality of } \\
\text { Religiosity }\end{array}$ & $\begin{array}{l}\text { Dimensi Intelektual } \\
\text { Dimensi Ideologi }\end{array}$ & 0.02 & 1 & 0.88570 & 0.000 \\
\hline & & Dimensi Ibadah kelompok & 0.89 & 1 & 0.34416 & 0.000 \\
\hline & & Dimensi Ibadah Individu & 0.11 & 1 & 0.73939 & 0.000 \\
\hline & & Dimensi Pengalaman Religius & 0.46 & 1 & 0.49728 & 0.000 \\
\hline
\end{tabular}

Berdasarkan tabel di atas dapat diketahui bahwa seluruh alat ukur menunjukkan P-value $>0.05$ dan RMSEA $<0.05$, sehingga seluruh model dinyatakan fit.

\section{Tabel 4}

$R$-Square

\begin{tabular}{ccccc}
\hline Model & $R$ & $R$-Square & Adjusted R-Square & Std. Error of the estimate \\
\hline 1 & $.705^{\mathrm{a}}$ & .498 & .477 & $\mathbf{6 . 9 5 2 2 1}$ \\
\hline
\end{tabular}

Hasil uji hipotesis yang dilakukan dengan teknik analisis regresi berganda menunjukkan bahwa ada pengaruh yang signifikan dari perceived burdensomeness, thwarted belongingness, religiusitas, dan demografi terhadap ideasi bunuh diri pada lansia. Berdasarkan tabel diatas, perolehan R-Square adalah sebesar 0.498 yang berarti bahwa proporsi pengaruh dari perceived burdensomeness, thwarted belongingness, religiusitas, dan demografi terhadap ideasi bunuh diri pada lansia sebesar $49.8 \%$ dan sisanya $50.2 \%$ dipengaruhi oleh variabel lain diluar penelitian.

Tabel 5

Annova

\begin{tabular}{llccccc}
\hline Model & & Sum of Square & Df & Mean Square & F & Sig. \\
\hline 1 & Regression & 10529.736 & 9 & 1169.971 & 24.206 & $.000^{\mathrm{b}}$ \\
& Residual & 10633.315 & 220 & 48.333 & & \\
& Total & 21163.051 & 229 & & & \\
\hline
\end{tabular}

Berdasarkan data diatas, ada nilai signifikansi perceived burdensomeness, thwarted belongingness, religiusitas, dan demografi terhadap ideasi bunuh diri pada lansia. Nilai signifikansi Sig.000 (sig. <0.05) menunjukkan bahwa pengaruh perceived burdensomeness, thwarted belongingness, religiusitas, dan demografi terhadap ideasi bunuh diri pada lansia signifikan. 
Tabel 6

Koefisien Regresi

\begin{tabular}{lrrrrr}
\hline Model & \multicolumn{2}{c}{$\begin{array}{c}\text { Unstandardized } \\
\text { Coefficients }\end{array}$} & $\begin{array}{c}\text { Standardized } \\
\text { Coefficients } \\
\text { Beta }\end{array}$ & \multicolumn{1}{c}{ T } & Sig. \\
& \multicolumn{1}{c}{ B } & Std. Error & \multicolumn{2}{c}{. } & \\
\hline 1 (Constant) & 34.923 & 6.549 & .332 & .000 \\
Burdensomeness & .511 & .057 & .517 & 9.019 & $.000^{*}$ \\
Belongingness & .070 & .064 & .066 & 1.095 & .275 \\
Intelek & .114 & .077 & .104 & 1.467 & .144 \\
Ideologi & -.272 & .070 & -.262 & -3.868 & $.000^{*}$ \\
Kelompok & -.100 & .064 & -.093 & -1.565 & .119 \\
Individu & -.138 & .080 & -.125 & -1.737 & .084 \\
Pengalaman & .076 & .080 & .071 & .944 & .346 \\
JenisKelamin & 1.199 & 1.011 & .060 & 1.186 & .237 \\
Pendidikan & .023 & .391 & .003 & .059 & .953 \\
\hline
\end{tabular}

*Signifikan

Berdasarkan tabel 4 di atas, signifikansi masing - masing dari independent variable dilihat dari nilai sig. Nilai sig < 0.05 menunjukkan bahwa koefisien regresi yang dihasilkan adalah signifikan. Dari hasil diatas dapat dilihat bahwa ada dua variabel signifikan yaitu perceived burdensomeness dan ideologi. Tujuh variabel lainnya yaitu thwarted belongingness, intelektual, ibadah kelompok, ibadah individu, pengalaman religius, jenis kelamin dan tingkat pendidikan tidak memiliki pengaruh yang signifikan terhadap ideasi bunuh diri pada lansia.

\section{Diskusi}

Dari uji regresi ganda, diketahui bahwa secara simultan (bersama-sama) terdapat pengaruh yang signifikan dari variabel perceived burdensomeness, thwarted belongingness, religiusitas (intelektual, ideologi, ibadah kelompok, ibadah individu, dan pengalaman religius) dan demografi (jenis kelamin dan tingkat pendidikan) terhadap ideasi bunuh diri pada lansia. Meski demikian, jika dianalisis secara parsial, hanya perceived burdensomeness dan dimensi ideologi dari variabel religiusitas yang berpengaruh signifikan terhadap ideasi bunuh diri pada lansia.

Perceived burdensomeness diketahui memiliki pengaruh yang signifikan serta bermuatan positif terhadap ideasi bunuh diri lansia, yang berarti bahwa semakin tinggi perceived burdensomeness yang dirasakan lansia, maka semakin tinggi pula kemungkinan munculnya ideasi bunuh diri. Temuan ini sejalan dengan penelitian dari Cukrowicz, Cheavens, Orden, Ragain, \& Cook (2011) yang menyebutkan perceived burdensomeness sebagai salah satu jembatan antara ideasi bunuh diri dan lansia. Hal ini mungkin disebabkan karena pada kelompok umur lansia, keadaan fisik dan mental yang menurun membuatnya sangat membutuhkan bantuan orang lain. Dengan demikian lansia merasa bahwa dirinya beban untuk orang sekitar yang harus mengurusnya. Jika dikaitkan dengan Indonesia, yang sebagaimana diketahui menganut budaya ketimuran dan memegang teguh tata krama, wajib hukumnya bagi seorang untuk menghormati dan berbakti pada orangtua, terutama yang telah memasuki usia lanjut. Di sisi lain, budaya ini menyebabkan orangtua selalu memandang anak sebagai sosok yang perlu diayomi, yang berdampak pada orangtua selalu menunjukkan ketegaran sebagai panutan sang anak, meskipun ketika anak telah dewasa. Orangtua tidak suka menunjukkan sisi 
lemahnya pada anak, karenanya ketika mereka merasa membebani, stress dan pikiran bunuh diri dapat muncul. Campos, Santos, Piteira, Abreu, \& Tavares (2018) pada penelitiannya tidak menemukan adanya pengaruh signifikan antara perceived burdensomeness dan ideasi bunuh diri pada lansia, namun mereka membandingkan hasil penelitiannya dengan penelitian dari Kanzler, Bryan, Mcgeary, \& Morrow (2012) yang menyatakan sebaliknya. Mereka memprediksi penyebab dari kesenjangan hasil itu adalah perbedaan responden, dimana dalam penelitian Campos et al. (2018) sampel yang diambil adalah pasien yang telah sembuh dari penyakit akut, sedangkan pada penelitian Kanzler et al. (2012) sampelnya adalah penderita penyakit kronis. Dengan demikian disimpulkan kondisi kesehatan kemungkinan merupakan mediasi antara perceived burdensomeness dengan ideasi bunuh diri lansia. Sayangnya variabel kesehatan tidak diteliti dalam penelitian ini.

Pada variabel thwarted belongingness, tidak ditemukan pengaruhnya yang signifikan terhadap ideasi bunuh diri pada lansia. Temuan ini bertolak belakang dengan hasil penelitian dari Campos et al. (2018) dan McLaren, Gomez, Gill, \& Chesler (2015). Peneliti berpendapat adanya diskrepansi hasil penelitian ini kemungkinan disebabkan oleh perbedaan kultur negara. Penelitian-penelitian yang disebutkan sebelumnya dilakukan di negara barat (Portugis dan Australia), yang mana nilai-nilai individualisme sangat ditekankan, sehingga rasa terasingkan dari lingkungan sekitar (thwarted belongingness) cenderung lebih mudah muncul dibandingkan negara timur yang kental dengan nilai kolektivisme dan norma-norma kekeluargaan. Di Indonesia sendiri, adalah hal umum untuk tinggal bersama keluarga. Hal ini terbukti dari jumlah lansia yang tinggal sendiri hanya sebanyak 6,5\% dari seluruh responden. Sementara itu, dari data tabulasi silang, dapat dilihat bahwa lansia yang tinggal sendiri cenderung memiliki ideasi bunuh diri yang tinggi, sesuai dengan penelitian-penelitian sebelumnya yang menyebutkan bahwa lansia yang tinggal sendiri lebih mungkin mengalami ideasi bunuh diri dibandingkan situasi hidup lainnya (Ju et al., 2016; Kim, Lee, \& Lee, 2016). Sehingga dapat disimpulkan tidak signifkannya thwarted belongingness pada ideasi bunuh diri lansia disebabkan oleh sebaran data yang tidak merata.

Berlanjut ke variabel religiusitas, dari hasil pencarian peneliti, belum ada studi perihal korelasi antara religisusitas dan ideasi bunuh diri spesifik pada kelompok umur lansia, apalagi yang menghubungkan religiusitas dengan ideasi bunuh diri menggunakan dimensi dari Huber \& Huber (2012). Oleh sebab itu, peneliti akan membandingkan hasil penelitian ini dengan penelitian-penelitian sebelumnya yang berhubungan namun tidak secara langsung dengan ideasi bunuh diri dan dimensidimensi variabel religiusitas.

Berdasarkan hasil pengolahan statistik, diperoleh data yang menunjukkan dari kelima dimensi hanya satu yang terbukti mempengaruhi ideasi bunuh diri pada lansia secara signifikan, yaitu dimensi ideologi. Dimensi lainnya, yaitu intelektual, ibadah kelompok, ibadah individu, dan pengalaman religius ditemukan tidak mempengaruhi ideasi bunuh diri pada lansia.

Dimensi religiusitas pertama yang akan dibahas adalah intelektual. Dimensi ini diketahui tidak memiliki pengaruh yang signifikan terhadap ideasi bunuh diri lansia, yang mungkin dikarenakan tidak adanya alat ukur yang benar-benar mengukur intelektual religiusitas responden. Hasil yang didapat di penelitian ini hanya intelektual religiusitas yang dirasakan bukan yang sesungguhnya. Padahal pada penelitian sebelumnya disimpulkan bahwa dengan meningkatnya dimensi-dimensi agama (kepercayaan, emosi, pengetahuan, hasil, dan ritual) maka kemungkinan munculnya ideasi bunuh diri akan menurun (Lotfi, Ayar, \& Shams, 2012).

Berikutnya pada dimensi ideologi dari variabel religiusitas ditemukan dari hasil statistik memiliki pengaruh yang signifikan terhadap ideasi bunuh diri lansia. Temuan ini berhubungan dengan hasil dari Lotfi et al. (2012) yang menyatakan bahwa semakin tinggi kepercayaan agama, maka persentase probabilitas munculnya ideasi bunuh diri akan menurun. Peneliti menganggap hal ini disebabkan karena keyakinan adalah fondasi awal dalam religiusitas. Dampak positif dari agama akan berkurang apabila keyakinan terhadap agama itu sendiri rendah. Individu yang memiliki keyakinan tinggi terhadap agamanya akan mentaati larangan agama perihal perilaku bunuh diri, serta doa dan ibadah 
yang dilakukan sebagai pencegah pikiran-pikiran intrusif akan memiliki dampak yang optimal, sehingga menurunkan probabilitas munculnya ideasi bunuh diri.

Dimensi ibadah kelompok dan ibadah individu dari variabel religiusitas sama-sama tidak memiliki pengaruh yang signifikan terhadap ideasi bunuh diri pada lansia. Hasil penelitian ini sejalan dengan penelitian dari Vasegh \& Mohammadi (2007) yang tidak menemukan adanya korelasi yang signifikan antara perilaku keagamaan atau ibadah dengan depresi dan kecemasan, namun berbanding terbalik dari penelitian Taliaferro, Rienzo, Pigg, Miller, \& Dodd (2009) yang menyatakan bahwa partisipasi dalam kegiatan keagamaan (ibadah kelompok) berkorelasi negatif dengan ideasi bunuh diri dan depresi, serta penelitian dari Cole-Lewis, Gipson, Opperman, Arango, \& King (2016) yang menyimpulkan bahwa ibadah individual berkorelasi negatif dengan ideasi bunuh diri dan gejala depresi sedangkan partisipasi organisasi keagamaan (ibadah kelompok) berkorelasi negatif dengan gejala depresi. Seperti telah disebutkan sebelumnya, kepercayaan adalah fondasi awal dalam religiusitas. Ibadah dan doa yang dilakukan apabila dilakukan tanpa keyakinan hanya akan menjadi rutinitas biasa. Peneliti berpendapat ini lah penyebab dimensi ibadah, baik individu maupun kelompok tidak memiliki pengaruh signifikan terhadap ideasi bunuh diri, karena ibadah hanya dilakukan sebagai rutinitas dan kewajiban, tanpa diyakini manfaatnya atau dikhidmati prosesnya, terutama pada dimensi ibadah kelompok yang sifatnya kurang intim dibandingkan ibadah individu. Pada teori Orientasi Religius, ibadah kelompok dapat dihubungkan dengan orientasi religius ekstrinsik, dimana aspek ibadah dilakukan untuk mendapatkan sebuah keuntungan tersendiri (Allport \& Ross, 1967), karenanya cukup wajar apabila dikatakan tingkat ibadah kelompok tidak mempengaruhi ideasi bunuh diri.

Dimensi terakhir dari variabel religiusitas, yaitu pengalaman religius, yang diketahui pengaruhnya tidak signifikan terhadap ideasi bunuh diri pada lansia. Hasil ini cukup menarik karena menurut asumsi peneliti, individu yang merasa terhubung dengan Tuhan seharusnya memiliki religiusitas yang tinggi, terutama dalam aspek keyakinannya pada agama atau Tuhan. Oleh sebab itu, tidak signifikannya dimensi ini terhadap ideasi bunuh diri pada lansia mungkin disebabkan oleh seluruh responden penelitian yang memiliki rasa terhubung dengan Tuhan yang setara sehingga tidak memberikan pengaruh yang berarti pada penelitian ini.

Berikutnya adalah faktor demografi, yaitu jenis kelamin dan tingkat pendidikan. Pertama, jenis kelamin ditemukan tidak memiliki pengaruh yang signifikan terhadap ideasi bunuh diri pada lansia, artinya, tidak ada perbedaan gender dalam kemunculan ideasi bunuh diri. Menurut opini peneliti, tiap gender memiliki masalahnya masing-masing dalam menghadapi usia tua. Perempuan lebih rentan ketika mereka menghadapi peristiwa negatif, seperti kegagalan perkawinan dan tekanan emosional. Pria mengutamakan finansial, status, dan kekuatan sebagai kebanggaan. Memasuki usia lanjut, halhal tersebut akan berkurang secara drastis, membuat pria mudah merasa stress dan depresi. Meskipun berbeda, baik pria maupun wanita memiliki masalah setara dalam konteks menjelang usia tua. Penemuan ini sejalan dengan hasil dari Xu et al. (2016) yang menyebutkan tidak ada perbedaan signifikan antara lansia pria dan wanita dalam ideasi bunuh diri, namun bertolak belakang dengan hasil dari Jang et al. (2014) dan Zhang et al. (2017) yang menyebutkan wanita lebih rentan dengan ideasi bunuh diri.

Tingkat pendidikan sebagai faktor terakhir dari penelitian ini juga diketahui tidak mempengaruhi ideasi bunuh diri pada lansia secara signifikan. Hasil ini tidak konsisten dengan penelitian dari Bickford, Morin, Nelson, \& Mackin (2019), Jang et al. (2014), dan Yu et al. (2019), yang menemukan adanya korelasi negatif antara tingkat pendidikan dengan ideasi bunuh diri pada lansia. Perbedaan hasil penelitian ini mungkin disebabkan oleh sebaran responden yang tidak merata pada kategori tingkat pendidikan.

Penulis juga menyadari adanya keterbatasan-keterbatasan dalam penelitian ini. Keterbatasan pertama, dikarenakan pandemi Covid-19, penulis tidak dapat menyebar kuesioner secara face-to-face dengan responden, mengingat lansia sebagai kelompok usia paling rentan tertular virus ini. Meskipun penulis mungkin tidak terpapar virus Covid-19 sehingga tidak mungkin menularkannya pada 
responden, responden khawatir kehadiran penulis di sekitar responden yang telah lanjut usia akan menimbulkan ketidaknyamanan. Penulis terpaksa melakukan penyebaran kuesioner secara online menggunakan googleform. Metode ini membuka peluang untuk bias respon social desirability, terutama apabila responden dalam pengisian kuesionernya perlu dibantu orang sekitarnya. Karena metode ini pula, apabila responden tidak paham terhadap item yang diberikan, kemungkinan responden menghubungi penulis sangat kecil dan akan mengisi sepahamnya, sehingga hasil yang didapat bukan hasil sesungguhnya dari responden.

Keterbatasan terakhir adalah hasil dari analisis regresi yang menunjukkan dari tujuh variabel yang diteliti, hanya dua variabel yang mempengaruhi variabel dependen. Ini mengindikasikan bahwa dalam penelitian ini, penulis masih kurang menelaah lebih lanjut perihal variabel-variabel lain yang menjadi prediktor dari ideasi bunuh diri pada lansia. Penulis sangat menyadari kekurangan dan keterbatasan dalam penelitian yang telah dilakukan ini, sehingga dibutuhkan penelitian lebih lanjut untuk melengkapi kekurangan dan keterbatasan dalam penelitian ini.

Untuk saran teoritis, bagi peneliti selanjutnya yang juga ingin meneliti ideasi bunuh diri pada lansia, penulis menyarankan agar meneliti serta menganalisis pengaruh dari variabel lain yang juga mempengaruhi ideasi bunuh diri namun hasil-hasil penelitiannya masih tidak konsisten, seperti kondisi kesehatan, penyakit, pengaruh peristiwa besar, hubungan sosial, wilayah, restricted activity (terbatasnya aktivitas akibat gangguan fisik), serta living arrangement atau situasi hidup, terutama antara lansia yang tinggal dengan keluarga dan lansia yang tinggal di panti werdha. Selain itu, berdasarkan penelitian ini terdapat beberapa item yang masih memiliki kalimat ambigu dikarenakan dari diadaptasi dari skala berbahasa Inggris. Untuk penelitian selanjutnya, diharapkan untuk memerhatikan tiap-tiap item yang akan digunakan dalam penelitian. Pada penelitian ini, DV yang digunakan adalah ideasi bunuh diri sebagai alternatif aksi bunuh diri yang berhasil, dikarenakan kesulitan dalam pengambilan data. Padahal fakta yang menarik adalah lansia sebagai kelompok usia yang melakukan aksi bunuh diri tertinggi dibanding kelompok usia lainnya. Karenanya, pada peneliti selanjutnya yang ingin meneliti tentang bunuh diri pada lansia, penulis menyarankan untuk menggunakan aspek aksi bunuh diri yang berhasil, dengan menggunakan data statistik bunuh diri dan melakukan autopsi psikologis, untuk mendapat jawaban yang lebih pasti dari fenomena menarik ini.

Ditinjau dari hasil penelitian, variabel independen yang memiliki pengaruh yang signifikan terhadap ideasi bunuh diri pada lansia antara lain yaitu perceived burdensomeness dan ideologi religiusitas, sehingga penulis memberikan saran aplikatif dari penelitian ini untuk meningkatkan kesadaran masyarakat untuk tidak membuat kerabat atau kenalan yang telah memasuki lanjut usia merasa menjadi beban di lingkungannya. Apabila masih mampu, ada baiknya untuk memotivasi lansia untuk melakukan kegiatan sehari-hari ataupun kegiatan kecil lainnya. Selain itu, disarankan pula untuk lansia agar tetap mempertahankan dan meningkatkan keimanan yang sudah dimiliki agar dapat tercipta kehidupan yang tentram dan bahagia.

\section{Kesimpulan}

Berdasarkan uji hipotesis regresi berganda, secara simultan ditemukan semua variabel memprediksi ideasi bunuh diri, tetapi melalui koefisien regresi secara parsial hanya ada dua variabel yang ditemukan signifikan menjelaskan ideasi bunuh diri, yakni perceived burdensomeness dan dimensi ideologi dari variabel religiusitas. Sementara itu, secara parsial, variabel lain yakni thwarted belongingness, dimensi intelektual, ibadah kelompok, ibadah individu, dan pengalaman religius dari variabel religiusitas, serta jenis kelamin dan tingkat pendidikan dari variabel demografi tidak signifikan memprediksi ideasi bunuh diri pada lansia. 


\section{Daftar Pustaka}

Allport, G. W., \& Ross, J. M. (1967). Personal religious orientation and prejudice. Journal of Personality and Social Psychology, 5(4), 432-443. https://doi.org/10.1037/h0021212

Beck, A. T., \& Kovacs, M. (1979). Assessment of Suicidal Intention: The Scale for Suicide Ideation. Journal of Consulting and Clinical Psychology, 47(2), 343-352. https://doi.org/https://doi.org/10.1037//0022-006x.47.2.343

Bengtson, V. L., Silverstein, M., Putney, N. M., \& Harris, S. C. (2015). Does Religiousness Increase with Age? Age Changes and Generational Differences Over 35 Years. Journal for the Scientific Study of Religion, 54(2), 363-379. https://doi.org/10.1111/jssr.12183

Bickford, D., Morin, R. T., Nelson, J. C., \& Mackin, R. S. (2019). Determinants of Suicide-related Ideation in Late Life Depression: Associations with Perceived Stress. Clinical Gerontologist, OO(00), 1-9. https://doi.org/10.1080/07317115.2019.1666442

Campos, R. C., Santos, S., Piteira, M., Abreu, M., \& Tavares, S. (2018). Interpersonal Needs, Depressive Symptoms, and Suicide Ideation in a Sample of Portuguese Elderly Patients Recovering from Acute Medical Conditions. Journal of Clinical Psychology in Medical Settings, 25(1), 0. https://doi.org/10.1007/s10880-017-9520-0

Cole-Lewis, Y. C., Gipson, P. Y., Opperman, K. J., Arango, A., \& King, C. A. (2016). Protective Role of Religious Involvement Against Depression and Suicidal Ideation Among Youth with Interpersonal Problems. Journal of Religion and Health, 55(4), 1172-1188. https://doi.org/10.1007/s10943-016-0194-y

Crestani, C., Masotti, V., Corradi, N., Schirripa, M. L., \& Cecchi, R. (2019). Suicide in the elderly: A 37-years retrospective study. Acta Biomedica, 90(1), 68-76. https://doi.org/10.23750/abm.v90i1.6312

Cukrowicz, K. C., Cheavens, J. S., Orden, K. A. Van, Ragain, R. M., \& Cook, R. L. (2011). Perceived Burdensomeness and Suicide Ideation in Older Adults. Psychology and Aging, 26(2), 331-338. https://doi.org/10.1037/a0021836

David Klonsky, E., \& May, A. M. (2015). The three-step theory (3ST): A new theory of suicide rooted in the "ideation-to-action" framework. International Journal of Cognitive Therapy, 8(2), 114-129. https://doi.org/10.1521/ijct.2015.8.2.114

Heisel, M. J., \& Flett, G. L. (2006). The development and initial validation of the Geriatric Suicide Ideation Scale. American Journal of Geriatric Psychiatry, 14(9), 742-751. https://doi.org/10.1097/01.JGP.0000218699.27899.f9

Huber, S., \& Huber, O. W. (2012). The Centrality of Religiosity Scale (CRS). Religions, 3(3), 710724. https://doi.org/10.3390/rel3030710

Jang, S. Y., Choi, B., Ju, E., Kim, Y. M., Kang, S., Park, S., ... Kim, I. (2014). Association between restriction of activity related to chronic diseases and suicidal ideation in older adults in Korea. Geriatr Gerontol, 14, 983-988. https://doi.org/10.1111/ggi.12202

Jayani, D. H. (2019). Berapa Angka Bunuh Diri di Indonesia? Retrieved from databoks website: https://databoks.katadata.co.id/datapublish/2019/09/11/berapa-angka-bunuh-diri-di-indonesia

Joiner, T. E. (2005). Why People Die by Suicide. In Harvard University Press. https://doi.org/10.1017/CBO9781107415324.004

Ju, Y. J., Park, E. C., Han, K. T., Choi, J. W., Kim, J. L., Cho, K. H., \& Park, S. (2016). Low socioeconomic status and suicidal ideation among elderly individuals. International Psychogeriatrics, 28(12), 2055-2066. https://doi.org/10.1017/S1041610216001149

Jung, J., Roh, D., Moon, Y. S., \& Kim, D. H. (2017). The Moderating Effect of Religion on the 
Relationship between Depression and Suicidal Ideation in the Elderly. Journal of Nervous and Mental Disease, 205(8), 605-610. https://doi.org/10.1097/NMD.0000000000000637

Kanzler, K. E., Bryan, C. J., Mcgeary, D. D., \& Morrow, C. E. (2012). Suicidal Ideation and Perceived Burdensomeness in Patients with Chronic Pain. Pain Practice, 12(8), 602-609. https://doi.org/10.1111/j.1533-2500.2012.00542.x

Khalik, A. (2020). Diduga Depresi, Seorang Lansia Ditemukan Tewas Gantung Diri. Retrieved July 24, 2020, from Timlo website: https://timlo.net/baca/78854/diduga-depresi-seorang-lansiaditemukan-tewas-gantung-diri/

Kim, J., Lee, Y. S., \& Lee, J. (2016). Living arrangements and suicidal ideation among the Korean older adults. Aging and Mental Health, 20(12), 1305-1313. https://doi.org/10.1080/13607863.2015.1078280

Lotfi, Y., Ayar, A., \& Shams, S. (2012). The Relation Between Religious Practice and Committing Suicide: Common and Suicidal People in Darehshahr, Iran. Procedia - Social and Behavioral Sciences, 50(July), 1051-1060. https://doi.org/10.1016/j.sbspro.2012.08.105

Maylasari, I., Rachmawati, Y., Wilson, H., Nugroho, S. W., Sulistyowati, N. P., \& Dewi, F. W. R. (2019). Statistik Penduduk Lanjut Usia 2019. Jakarta: Badan Pusat Statistik.

McLaren, S., Gomez, R., Gill, P., \& Chesler, J. (2015). Marital status and suicidal ideation among Australian older adults: The mediating role of sense of belonging. International Psychogeriatrics, 27(1), 145-154. https://doi.org/10.1017/S1041610214001501

Menec, V. (2012). Why seniors matter - and how they contribute to our everyday lives. Retrieved September 3, 2020, from EvidenceNetwork website: https://evidencenetwork.ca/why-seniorsmatter-and-how-they-contribute-to-our-everyday-lives-2/

Nock, M. K., Borges, G., Bromet, E. J., Cha, C. B., Kessler6, R. C., \& Lee, S. (2008). Suicide and Suicidal Behavior. Epidemiol Rev, 30(1), 133-154. https://doi.org/10.1093/epirev/mxn002.Suicide

Orden, K. A. Van, Cukrowicz, K. C., Witte, T. K., \& Joiner, T. E. (2012). Thwarted Belongingness and Perceived Burdensomeness: Construct Validity and Psychometric Properties of the Interpersonal Needs Questionnaire. Psychol Assess, 24(1), 197-215. https://doi.org/10.1556/MPSzle.62.2007.1.2

Pangaribowo, W. S. (2019). Diduga Depresi dan Sakit Menahun Lansia di Gunungkidul Ini Gantung Diri. Retrieved July 23, 2020, from Tribun Jogja website: https://jogja.tribunnews.com/2019/08/01/diduga-depresi-dan-sakit-menahun-lansia-digunungkidul-ini-gantung-diri

Pertana, P. R. (2019). Tragis! Di Gunungkidul, Banyak Lansia Gantung Diri karena Kesepian. Retrieved July 24, 2020, from Detik Health website: https://health.detik.com/beritadetikhealth/d-4523777/tragis-di-gunungkidul-banyak-lansia-gantung-diri-karena-kesepian

Reynolds, W. M. (1991). Psychometric Characteristics of the Adult Suicidal Ideation Questionnaire in College Students. Journal of Personality Assessment, 56(2), 289-307. https://doi.org/10.1207/s15327752jpa5602_9

Ron, P. (2008). Depression, Hopelessness, and Suicidal Ideation Among the Elderly. Journal of Gerontological Social Work, (September 2014), 37-41. https://doi.org/10.1300/J083v43n02

Satrianegara, M. F. (2014). Pengaruh Religiusitas Terhadap Tingkat Depresi, Kecemasan, Stres, Dan Kualitas Hidup Penderita Penyakit Kronis Di Kota Makassar (Kajian Survei Epidemiologi Berbasis Integrasi Islam Dan Kesehatan). Kesehatan, 6(Cdc), 288-304. https://doi.org/https://doi.org/10.24252/kesehatan.v7i1.947 
Shah, A., \& Chandia, M. (2010). The relationship between suicide and Islam: a cross-national study. Journal of Injury and Violence Research, 2(2), 93-97. https://doi.org/10.5249/jivr.v2i2.60

Taliaferro, L. A., Rienzo, B. A., Pigg, R. M., Miller, M. D., \& Dodd, V. J. (2009). Spiritual wellbeing and suicidal ideation among college students. Journal of American College Health, 58(1), 83-90. https://doi.org/10.3200/JACH.58.1.83-90

Vasegh, S., \& Mohammadi, M. R. (2007). Religiosity, anxiety, and depression among a sample of iranian medical students. International Journal of Psychiatry in Medicine, 37(2), 213-227. https://doi.org/10.2190/J3V5-L316-0U13-7000

WHO. (2016a). Mental Health. Retrieved from World Health Organization website: https://www.who.int/mental_health/prevention/suicide/suicideprevent/en/

WHO. (2016b). Suicide rate estimates, crude, 10-year age groups, Estimates by country. Retrieved from World Health Organization website: http://apps.who.int/gho/data/node.main.MHSUICIDE10YEARAGEGROUPS?lang=en

Xu, H., Qin, L., Wang, J., Zhou, L., Luo, D., Hu, M., ... Xiao, S. (2016). A cross-sectional study on risk factors and their interactions with suicidal ideation among the elderly in rural communities of Hunan, China. BMJ Open, 6(4), 7-9. https://doi.org/10.1136/bmjopen-2015-010914

Yu, Z., Xu, L., Sun, L., Zhang, J., Qin, W., Li, J., ... Xie, S. (2019). Association between interpersonal trust and suicidal ideation in older adults: A cross-sectional analysis of 7070 subjects in Shandong, China. BMC Psychiatry, 19(1), 1-9. https://doi.org/10.1186/s12888-019-2186-4

Zhang, D., Yang, Y., Sun, Y., Wu, M., Xie, H., Wang, K., ... Su, Y. (2017). Characteristics of the Chinese rural elderly living in nursing homes who have suicidal ideation: A multiple regression model. Geriatric Nursing, 38(5), 423-430. https://doi.org/10.1016/j.gerinurse.2017.02.005 